\section{Skabelse gennem erindring}

Et komparativt essay om Giulio Camillos og Giordano Brunos mnemoteknik

KAREN DE LEÓN-JONES

Slægtskabet mellem Giulio Camillo Delminios (ca. 480-I544) berømte mnemotekniske værk L'idea del theatro (IS50) og Giordano Brunos (de Nola 1548 I600) La cabala del cavallo pegaseo ( 1585 ) er måske ikke umiddelbart tydelig, bortset fra at begge værker er påvirket af kabbalaen. Selvom Frances Yates, Paolo Rossi og andre har påvist, at erindringskunsten er en integreret del af Brunos filosofi, har dette dog ikke veret tilfoldet med Caber, som dette levet fundet for obskur, men hor dog erindring $e$ det primære spørgsmål, og hvor fremstillingen af sefirotisk kosmologi og af kabbalistiske ideer $i$ arketypiske billeder tydeligt er tænkt som måder at lette hukommelsen på. At værket blev betragtet som obskurt skyldtes til at begynde med den skandale, som dets publikation fremkaldte, og som tvang Bruno til at tage afstand fra værket, hvilket nødvendigvis begrænsede dets indflydelse, trods kabbalaens popularitet blandt kristne intellektuelle i det sekstende århundrede. Siden middelalderen havde kabbalistiske elementer været brugt i kristen kunstig hukommelse, og brugen var oget efter udbredelsen af Giovanni Pico della Mirandolas ( $4463-1494$ ) filosofise skrifter med deres lristo fortolkninger af kasosk i slutingen af det slutoingen af det fentende arhundrede. Inden fo denne kristne tradicon var kabbalistisk mnemoteknik et middel til at kunne trænge ind i de guddommelige mysterier. Bâde Camillo og Bruno anså kabbalaen som et potentielt middel til at trænge ind til skabelsens direkte kilde: Den første bevæger eller arketypiske mens (Tanken), som også er erindringens evige kilde. For begge tænkere er erindring essentiel for den kreative proces, som i sig selv er essentiel for indsigt. Indsigten er gengivet i forestillinger,

PAssage 3I/32- I999 og det er deres kabbalistiske karakter og måden hvorpå de afdækkes, der er dette essays emne. Med værker, der er så forskellige i struktur og bredde som de to nævnte, er en indledende tematisk tilgang mere fyldestgørende end et forsøg på at gennemtvinge en intertekstuel sammenhæng, nå der ikke engang er sammenhæng i de kabbalistiske principper, som de to forfattere fremsetter. Tkke at principper, som de to fofatere fensatter. Ikke a ter skrifter or forfattere of var inkonelvete fa et vark til det naste. Tre temaer er centrale for erindringskunsten og $i$ særlig grad relevante i forhold til de to værker, det dreje sig om - locus, fantasia, imago. Disse vil blive genfortolket $\mathrm{i}$ overensstemmelse med begreber, som teksterne selv foreslår, for videre at diskutere det kabbalistiske indhold $i$ en moderne kontekst: verdener, rejse, forestilling.

Verkernes struktur og gjemed

Lidea del theatro er en skreven skitse af det erindringsteater, som Camillo forsøgte at bygge under protektion af generose velyndere. Teksten indles protektion af generose velynere. Teksten indledes med en dedikation og efterfølges af syv kapitle som beskriver indholdet af teatrets syv trivi
gende rækker, hver markeret af et billede.

Brunos $L a$ Cabala del cavallo pegaseo er det andet værk i en trilogi af metafysiske dialoger. Opbygningen består af en dedikation, en deklamation o tre dialoger, der hver adskilles af en sonet. Der e yderligere en vedhæftet dialog, som ikke vil blive diskuteret her. Frances Yates har skematiseret strukturen i Camillos erindringsteater og beskrevet Brunos utallige mnemotekniske skrifter i hendes uom-

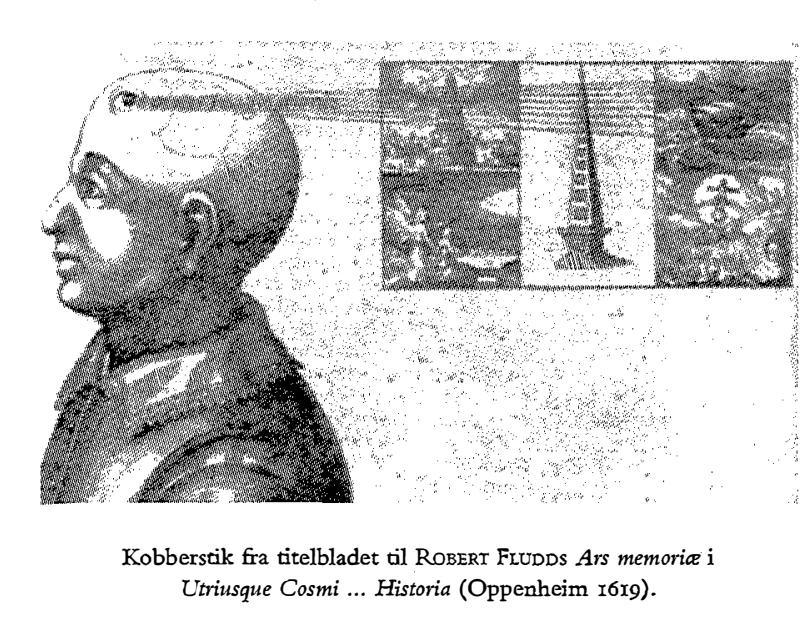

gængelige historiske oversigt, The Art of Memory, hvorfor jeg kun kort vil gennemgå værkernes indhold. Begge skitserer det kabbalistiske univers, som består af sefirot (guddommelige egenskaber eller emanationer) og deres tilsvarende hierarki af engle, som i den kristre tradition blev tilegnet Ptolemsus' som i den planetariske koss mellem de to For at vise at kablaten er grefor

grundlaget for hans erindringssystem, er Camillos teater understottet a syv søjler, som repræsenterer Salomons visdommens hus (Ordspr. 9.r). Salomon var almindeligvis formodet at være kabbalist, så med hans ry for stor visdom er det naturligt, at han skulle være den grundlæggende figur i teatret. De syv søjler er navngive efter syv sefirot, der er fulgt af de tilsvarende engle (Camillo, p. 60). Søjlerne er placeret på det der almindeligvis er teatrets scene, og de giver adgang til teatrets seks rækker. Trinene selv er præget af billede fra klassisk mytologi, som ikke desto mindre rum mer kabbalistiske begreber i den skreme tekst.

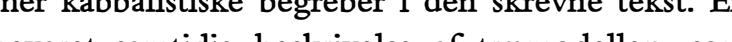
Coullo bygede i Vendig, for Camillo byggede i Venedig, findes i et brev skrevet 1532 af Vigulfus $Z$ (Yates (I966), pp. 131-32). Zuichemus forklarer, at teatre var malet med bileder pa huer trinrakke, som alle indeholdt kasser og skuffer fulde af papirer. Ud fra beskrivelsen er der tilsyneladende ikke noget usædvanligt ved teatrets grundlæggende idé, der antager, at den ældste visdomskilde, kabbalaen - legenden, der er tilskrevet Abraham, eller i det mindste formo- det at være visdomskilden for Moses og senere Sa lomon - er udgangspunkt for den søgen efter indsigt, der kunne nås både gennem tekst og billeder. Camillo ønskede tydeligvis, at teatret skulle være et lags erindringsredskab: det usedvanlige er, at $\mathrm{C}$ illo ville omsette den methefyike virklighed ti en fysisk.

Det fysike og metafysiske forenes ligeledes Det fysiske og metafysiske foreledes Cabala's mnemotekniske struktur, men på en mere subtil måde. Fremstillingen af sefirot og engle med de tilsvarende planeter følger middelalderens kendte erindringsskema over universets sfærer, som blev videreudviklet af Johannes Romberch $i$ hans afhandling om erindring, Congestorium artificiose memoriae (Is20). Først i fremstillingens slutning, efter den synkretistiske kosmologi er blevet klart statueret, viser det sig, at systemet har form som det sefirotiske træ, og ikke som det cirkelformede amfiteater, hvilket ville have været nærliggende $i$ betragtning af Brunos andre mnemotekniske skrifter, hvor dette den fortrulne model. I stedet for en mette 作 des en organisk arketype.

Hvad Bruno fastsætter som asinitàs træ overlejre i den sefirotiske form, og hvad Camillo kalder visdommens hus, hvilket svarer til et Vitruvius-inspireret teater bygget på et ældgammelt hebraisk fundament, synes altså ikke umiddelbart at være beslægtede, fordi de er fremstillet så forskelligt.

Erindringssystemerne har dog nogle fundamentale ligheder, hvilket viser kompleksiteten i den kristne kabbalistiske fortolkning af erindringskunsten. Tal er en primær komponent $i$ kabbalistisk fortolkningsteknik og fylder i begge systemer. Feks. presenterer de syv sefirot og systemer. Feks. reper ar a deriske og den guddom udelade Hokhmah, Binah og Keter reducerer nummeret fra ti til syv, finder sit fortifærlde i både kristne og jødiske numerologiske traditioner inden for kabbalaen. Ifølge Camillo er syv grundlaget for erindringsteatrets harmoniske dimensioner, fordi det $\mathrm{er}$ det perfekte tal, der forener alle modsætoinger, maskulin og feminin, eftersom det er skabt af lige og ulige tal $(3+4)$. Foreningen af maskulin og feminin 
er et neo-platonisk begreb som findes i den jødiske kabbala, hvor det spiller en anselig rolle i tidlige tekster som f.eks. Sefer Yetsirah og Zohar. Camillo tilkendegiver klart, at formålet med hans kabbalistiske fortolkninger, såvel som med hans brug af tekster af Hermes Trismegistos og af de klassiske allegorier, e deres utilgengelighed for de ulerte oo deres stimulerende virkning po de vardige (Camillo, p. s3). Belerende vikng rettigelsen a a vale des âbenbar, uigennemtrængeligt niveau i den arketypiske mens. Camillo mente, at selv ikke Moses havde nået erkendelsens niveau, Binah, ved den guddommelis åbenbaring på Sinai, og denne fortolkning er ganske enestående for en mand, der var berømmet hebraist og som var velbekendt med kabbalaens jødiske kilder.

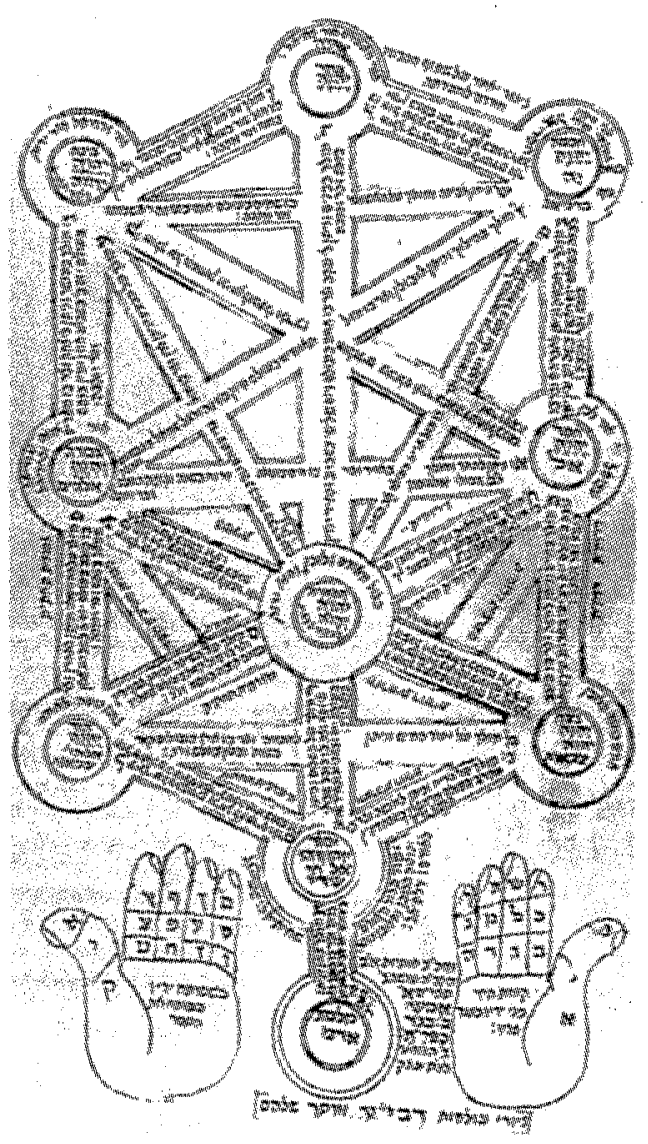

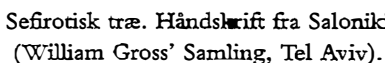

Camillos teater havde en indbygget adgangsbegrænsning, som skulle sørge for at indsigt kun kunne opnås gennem åbenbaring, men ikke af Gud. Den mest almindelige oversættelse af det hebraiske 'kabbala' er åbenbaring; gennem kabbalaen kan mennesket fâ adgang til det, som den arketypiske tanke tillader $i$ forestillingen. Det vil sige, teatrets mekaniske kvalitet jente som middel til at stimulere marere end il at gore fyldest. Den eneste vej for

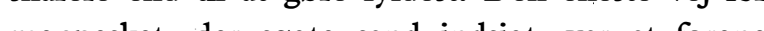
me den enkeltes vidn erkendelsen af den sande indsigt.

En af genialiteterne ved Camillos begreb er, at erindringsteatret både er et instrument, der tilskynder kreativitet ved at aktivere erindringsevnen, og et opbevaringssted for menneskelig kreativitet: det er

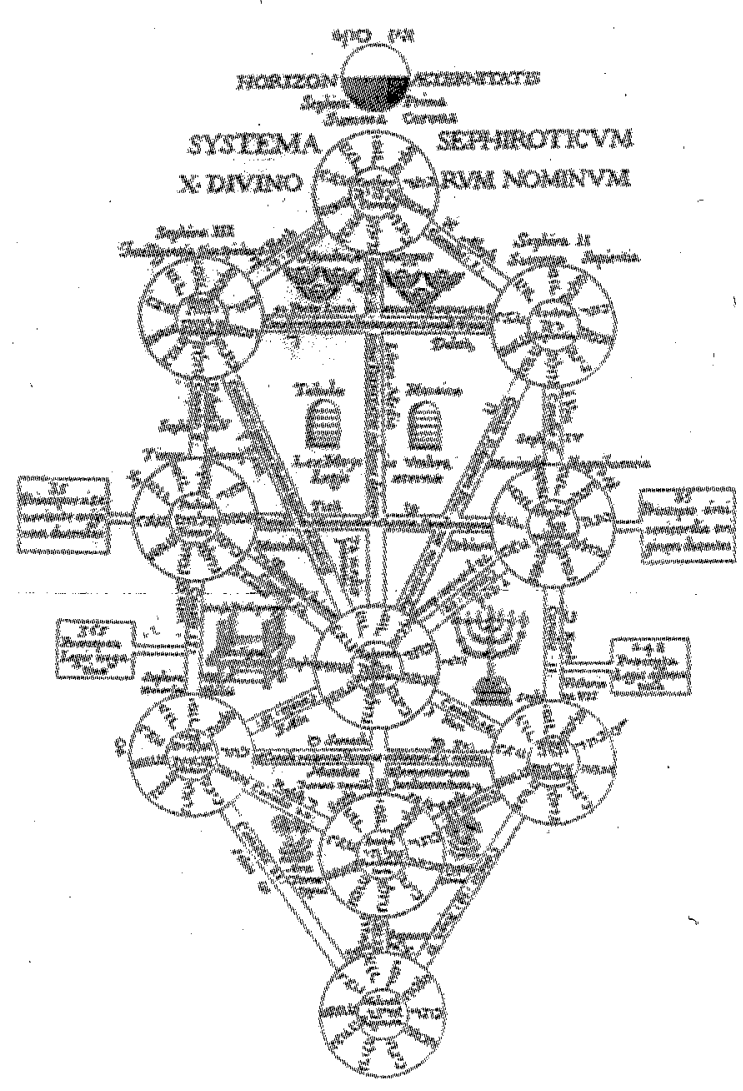

ATranastus KIrchrR: , ,efirot systemet", Oedipus Aegyptiacus (Rom ro63) både aktivt og passivt, coincidentia oppositorum. Bekendtheden i billeder og loci, hvad enten de kommer fra bibelske, kabbalistiske, hermetiske eller klassiske kilder, forstærker virkningen; selv teatrets struktur er bekendt hrilket teatre generelt var i det sterter men som Candllo oldidens Carte var helligesteder, og at de rituelle forestillinger opført for guderne var tæt forbundne med Apollons og Dionysos' mysteriekulter. Selvom denne funktion er fremmed for den jødiske tradition, er den ikke uforenelig med kabbalaen $i$ en kristen sammenhæng - hvad Pico definerede som guddommelige mysterier. Ud fra dette perspektiv genskabte Camillo oldtidens kultsteder $i$ en moderne kontekst. Det skal dermed ikke være sagt, at Camillo påtænkte at erstatte den kirkelige gudstjeneste, eftersom han hele sit liv var troende katolik, men at han fremsatte en ny åndelig retning.

Halvtreds år senere, da Bruno begrndte at skrive, ar shisen ar ser var skisen over sabt eller blot en har oplost i et utal af uforenelige sekter. Brunos brug af kabbalaen er strukturelt set mindre interessant end $\mathrm{Ca}$ millos. Ifølge Bruno var erindringskunstens fundamentale princip billedet; det vil sige, evnen til at skabe billeder der er unikke for det enkelte menneske og samtidig universelle nok til at skabe adgang til den arketypiske kilde. Hans erindringsredskab i Cabala er selve fantasien, som inspireres af en mental illustration af Romberchs sfæriske universmodel og af træets afbildning som også stammer fra sefirot kosmolooien. Billeder omdannes efter de behov, som informationerne, der skal senkaldes, stiller. Forst den kosion ler. Fost den kosmologiske struktror sefrot, dernæst disses træ-till iv som blyer til hagression, som genkalder universets sammensætning: sefirot manipuleres for at nedkalde deres tilstromning, deres arketypiske organiske funktion, det mystiske begreb om asinità og resultatet ved denne unio mystica, når visdommens urkilder forenes.

Der er i værket ingen yderligere forsøg på at animere selve erindringsstrukturen. Kabbalaen forsynede $i$ alt væsentligt Bruno med en forenelig kos- mologisk struktur, der er baseret på sefirot og Ein sof, som Bruno fortolkede i forhold til sit eget fysisk uendelige univers (eller ensofico universo"), oo i forhold til hvilken en metafysisk forste overlejres. Han erkendte uden tivl, at den kanne lister kabbatonelis il folion til fordel for en mere personlig og direkte vej, frem mod guddommelig indsigt. Men Bruno begrænsede sin brug af kabbalistiske elementer til de sefirot, der tydeligt er integrerede i Ptolemæus' kosmologi, såvel som til afbildningen af træet, som Bruno ikke să meget forbandt med skabelsens seks dage som med den korte tid i Edens have, med kundskabens træ, med menneskets gyldne tidsalder og syndefaldets følger.

Mens Camillo satte en begrænsning for menneskelig erkendelse, det vil sige uden for rekkevidde af Binah den anden Binat, den anden sefrah, troede Bror ma menneden for Brunos konde, uen er der enden af den for Branos kon som inkluderer menneskelig viden i den tredje sefrah Brunos kosmologiske system. Erkendelse eller Binah befinder sig i det stadigt genkendelige primum mobile, som i Brunos ældste kilder er del af universets fysiske struktur. Det er kun den første sefirah Keter, kronen, som befinder sig $\mathrm{i}$ den endelige dimension, det tiende lag hinsides Ptolemæus' kosmologi, Den første bevægers uudsigelige rige, og Brunos ensofiske univers. Drevet frem gennem Hokbmah kan menneskesindet her opnå en fuldstændig forening med det guddommelige intellekt, c derg foren og denst som Camllo ikke het tiende element ligna fon er ti pa same mide som Den forte beverer tal: på samme måde som Den første bevæger gennemtrænger al det værende for at forene universet enkeltdele $\mathrm{i}$ et. Bruno binder atomisme samme med kabbalaen for at kunne opnå den fulde harmon af modsætninger, som ligger hinsides adskillelsen mellem maskulin og ferninin, mellem animalsk og mineralsk. 
Begge systemer påstår at være mere end en erindringsmekanisme; et middel til at opnå guddommelig indsigt gennem direkte åbenbaring, overfort ved unio mystica. De filosofiske og teologiske implikationer ved systemernes synkretistiske struktur ligner tion vad systememes synketistiske struktur ligner ogsã hinanden i omfang, men ikke $i$ udvikling. Forskellene $i$ deres sto i deres mâsacting. Den komplekse og fysiske karakter ved Camillos teater er et forsøg på i en enkelt struktur at samle al erindringskraft, erfaring og eventuel opfyldelse af en videnskabelig og spirituel søgen. Men en sådan fordring er ikke til stede $\mathrm{i}$ det kabbalistiske erindringssystem, som Bruno fremsætter. Snarere end det er i sin konstruktion, er det modellens begrebslighed, der er mere radiær end Camillos, for Bruno argumenterer for en ubegrænset, nær guddommelig indsigt, som mennesket kan opnå gennem hans kabbala.

Locus - verdener

François Secret har $\mathrm{i}$ forskellige tekster, der omhandler det han kalder kristen kabbala, beskrevet kontinuiteten af kabbalistiske elementer $i$ udviklingen af mriemotelmisk kunst i det sekstende århundrede, og ofte i sammenhæng med begrebet om pluralisme i renæssancens tænkning (jvf. Secret). Pluralisme eller synkretisme som det betragtedes i det sekstende århundrede var beregnet til at udvikle en mere fuldstændig metafysisk erkendelse, og ikonografien som fulgte fra studiet af antikke kilder var formodet at stimulere erkendelsesevnen og øge vores conaissance. Resultatet i Camillos og Brunos skrifter er, at der inden for erindringssystemernes spatiale dimensioner er mangfoldige verdener, som kan kaldes hedenske, jødiske og kristne.

Opdeling og koncentration af vidner fundemenOpdeling og kundamentale for mnemoteleilken, eftersom systemerne skal bestemme og organisere det rum som informationerne optager, efter de er blevet afmærket. Inden for den antikke forstalse af sindet mente man, at hjernen var opdelt $i$ tre rum, saledes at det at stimulere eller genkalde erindring faktisk svarede til at skabe adgang til et særligt rum i sindet. De egenskaber som er indeholdt i sefirot frembyder mulige videnskategorier. Muligheden for at reorganisere sefi- rot $\mathrm{i}$ forskellige konfigurationer øger ligeledes de eller det sefirotiske menneske som en prototype for mikro/makrokosmos. Slutteligt tilføjer sefirot kosmologien to andre vigtige elementer: de fire varensverdener og Ein sof.

Her er det igen vigtigt at understrege de fysiske pekter ved Camillos teater, fordi det cent arot akker inden for tre din rum, som enindringen lat $i$ en dinsioner. Og dette er indesom er uden for og der materialiserer erindringsprocessen i sindet. Arkitekturen i renæssancen definerede rum ud fra omhyggelige beregninger af størrelser og proportioner, objektivt og kvantitetsbestemmende. Filosofisk baserede størrelser blev beregnet af æstetiske og funktionelle grunde og med det formål at påvirke både intellektuelt og fysisk. Oplevelsen af teatret skulle forene det objektive og Tvantitetsbestemmende med det subjektive og log

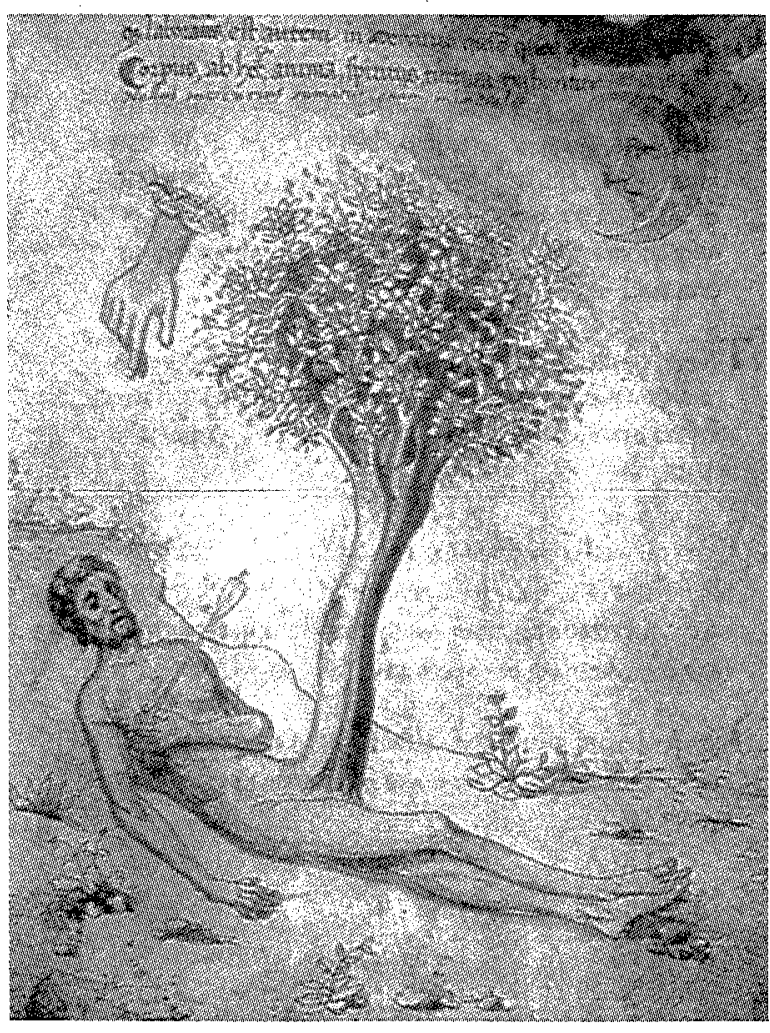

Adam, eller urmennesket.
Bibliotheca Medico-Laurenziana, Firenze, Ms. Ashbury, bl. í. (x. . arth.) litetsbestemmende og resulterer $i$ en forening af modsætninger. At bevæge sig, fysisk og metafysisk, gennem teatret svarede til at bevæge sig gennem de tre verdener. De syv søjler i visdommens hus er de syv sefirot, som bebor den guddommelige verden, sammen med engle og demoner, der kendes ico della

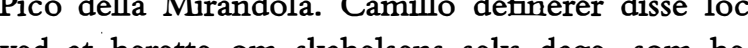
ved at be egner den jordiske verden, ved at skitsere de himmelske sfærer, der kommunikerer mellem verdene (ligesom Romberchs), og ved at beskrive den guddommelige verden. Menneskene bebor himlenes væld (rachia på hebraisk) i Gud Skaberens jordiske verden $i$ dens bibelske, hermetiske og kabbalistiske inkarnationer (jvf. Skabelsesberetningen, Poimandres, Zohar). En sjælden gang stiger menneskene op til den tredje himmel og skimter Gud, som Paulus (2. Kor. 12.2-4); men uvist af hvilken grund udelader Camillo kabbalaens fjerde verden. Der er ikke noget specielt originalt ved tredelingen af himmelse verder, det, der sto i skap ko in erindringsinstumenter, en at Camillo forestiller sig rum $i$ alle mulige doner tisk måd.

Teatrets konstruktion, eller blot dets imaginære rekonstruktion, gentager skabelsesprocessen og imiterer en kabbalistisk geming, der skal stimulere sefirots (eller andre billeders) påvirkning af mens, sà den fromme troende kan udrustes med kreativ kraft, hvilket dog ikke ændrer ved status quo. I den jødiske kabbala er det ofte ønsket, at den kreative kraft ska besjæle et kunstigt væsen, golem, som er den ultimative manifestation af det metafysiske i den fysiske verden. Skabelsen af et levende væsen ændrer nødvendigvis virkeligheden, eftersom intet vesen statisk (t) hans kkabelsens oprindelige gerning sig med den oprindelige erindring, der er oplagret 1 Den forste bevæger, og formålet er at ta et glimt af visdommens urkilde, for at menneskets indre kan fornyes, ikke for at skabe et andet væsen. Teatrets fysiske tilstedeværelse tjener til at placere mennesket $i$ skabelsen, a identificere mikrokosmos i makrokosmos. A hævde, at teatret repræsenterer lrop og sjel, at det er mikro- og makrokosmos, indebærer at teatret $i$ en jordisk legemlig betydning opfylder den funktion Adam Kadmon har i en kosmologisk

Det jordiske Paradis er et locus i Cabala, for Bruno var mere interesseret $i$ det skabte univers end i skabelsesprocessen. Snarere end at ville gradsbe stemme himmelske verdener, var det centrle i Bu( ct et uendeligt univers, der konstant bevæger sig og genskaber sig. Det eneste han beholder af den kabbalistiske verden er Ein sof, der nævnes som en betegnelse for universet, og som straks identificere med Den første bevæger, der gennemstrømmer al I Cabala bebor sefirot, med tilhørende engle og $\mathrm{d} x$ moner, saledes de specifikke sfærer i universet, sàdan som det opfattedes i slutningen af det sekstende århundrede. Hver enkelt sefirah betegnes af den tilsvarende planetariske eller himmelske sfære, og Bruno fokuserer på Hokhmah som locus, den ottende bevæoelsessfære, som fremdriver universet, stedet for asinità. Et andet locus er konfiguration,

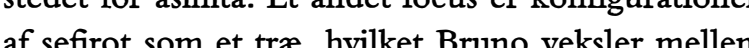
t brot at benzun som asintas tre og kundskabens tra. Iræets rod er sefrot, dets krone er arketypen eller asinita, og dets grene er de tre typer af negativ teologi, som defines tidligere i dialogen (Bruno, p. 876). Et diagram baseret på denne beskrivelse ville $\mathrm{i}$ betænkelig grad ligne Raymond Lulls (I235?-1315?) erindringstræ; et erindringsredskab, der var opstillet $\mathrm{i}$ tre forskellige afhandlinger, hvis titler peger på deres relevans: De memoria, De intellectu, De voluntate. Influeret af Lull opdeler og ordner Bruno således rum på et kosmologisk niveau, men modsat Camillo befolker han det også med besjælede væsener, der optræder som personer idialogen og som regelmassigt bryder de fysiske og metafysiske love.

Rum er fysisk for så vidt som kosmologien er del af den videnskabelige opfattelse af universet og dets funktion, således at sefirot bebor det samme heliocentriske univers, som Kopernicus forsøgte at definere. Rum er også metafysisk, fordi det indeholder abstrakte begreber som det mystiske asinità. Forskellige verdener eller dimensioner eksisterer side on side, f.eks. er der den tydeligvis ikke-jordiske verden, som samtalepartneren Onorio oplever; hvor 
floderne Lethe og Styx optræder sammen med Paradis, Elysion og andre billeder, der kendes fra traditionens over- og underjordiske rejseskildringer. Bruno bibeholder tanken om livet efter døden, men dets geografiske sted er knapt nok genkendeligt i forhold til en dantesk kunstig erindring. I det sekstende artundrede gionde den sidstronte ofte brug af $d e$ ofte bing af de tre niveauer i det kristne liv efter døden 1 thllnyning til det sfæriske univers-skema, som Romberch foretrak. Brunos kendskab til disse forskellige typer af erindringssystemer taget $i$ betragtning, er det sandsynligt, at Onorios bedrifter er tænkt som en manifestation af den funktionelle eller fungerende erindringskunst. Onorio er aktiv i alle de verdener han befinder sig i, og han ændrer i dem alle status quo. Det sker enten ved, at han nægter at drikke fra Lethe for dermed at bevare erindringen, så han forenes med Den første bevæger, eller ved at han, forvandlet som Pegasus, hjelper Perseus med at befri Andromeda, eller at han optræder $i$ inkarnationen of filoffen Aristotes. troder inkat

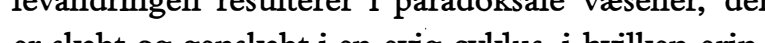
er skabt og genskabti en evig cyllus, i hivilken erindringen er gengivet, oplagret og genskabt gennem utallige inkarnatione

Forestillingen om livet efter døden, som Bruno fremstiller det i Cabala, er dér, hvor erindringen er bevaret gennem en evig cyklus af inkarnationer for de fẩ udvalgte, der accepterer, at det menneskelige sind er uvidende (i den sokratiske betydning). De imiterer de hellige kabbalister ved at forvandle sig til væsener, der er parate til en fuldstændig forening med det oprindelige intellekt, eller de opnår en direkte åbenbaring som det skete for profeterne i det Gamle Testamente. De, der opnår dette, er belonnet på forskellig vis: de vinder guddommelig indsist, ler de bliver remket i en ler de bliver rein vandring, som silrer en oprindelig evig erindring. Enhver diskussion af mikro- over for makrokosmos er fokuseret pà sjælens vandring, hjulpet af sefirah/sfæren Hokbmah, der er en radikal udvidelse af menneskelig viden, men dog stadig $i$ en uvidende form sammenlignet med den guddommelige indsigt, som kun kan gennemtrænges i Ein sof. Evigheden er en uendelig bevægelse af sjælen gennem verdener, sfærer, sind, kroppe og erindringer.

Fantasia - rejse

Den iboende dikotomi $\mathrm{i}$ begge de beskrevne systeDer illelsen mellem det fysise og det Det metaUy Ud over de postiter kan adskilelsen bedst bestrives $i$ samtidige termer som det, der ligger mellem en fysisk virkelighed og en fantastisk meta-virkelighed $i$ et område og $i$ en funktion af hjernen, som behandler erindring. Dette beskrivelsesgrundlag. havde medicinske og metafysiske konnotationer: fantasia var evnen til at stimulere de andre evner og åbne for tankeprocesser og erindring. Som Romberch illustrerer det i Congestorium artificiosa memoriae: påvirkningen passerer fra $\mathrm{de}$ ydre sanser til sensus communis i hjernens forreste del, går gennem fantasia til de nestfolgende rum, der indeholder evnerne: cogitativa, imaginativa, estimativa, memorativa Beval inaginativa, esti(a) hjencerion, kreativitet og erindring, pa samme made som bevægelse og fantasi er væsentligt for kunstig erindring. Bewagelse $i$ erindringskunsten er en middelalderlig fornyelse, som opstår i Raymond Lulls skrifter fra det trettende århundrede. Lull kunne dog ikke have forestillet sig en fysisk bevægelse inden for en tredimensional kunstig erindring. Ved fysisk at rejse gennem teatret kunne man trænge ind $i$ et forudfatte rum, som fysisk og metafysisk skulle betjenes af en vidensssøgende, der kunne gå fra scenen og op igennem publikumsrækkerne og vælge fra kasser og skuffer, der var fyldt med papirer og information Camillo aktiverede fysisk sit erindringrmationer.

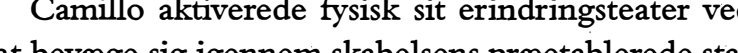
Cons præetablerede stader, hulket phcer tiske traditions beretwinger om skabelsen, der starter med Sefer Yetzirah eller Skabelsesbogen - måske de ældst bevarede kabbala-tekst, som sandsynligvis stammer fra det ottende århundrede. Der er uenighed om dets oprindelse, men uanset om det accepteres som den første kabbala-tekst, er det et af de værker som tydeligst har påvirket de jødiske kabbalister, såvel som de kristne efterfølgere, der finder en populær stemme i Pico della Mirandolas Heptaplus (1489), en kommentar om hver enkelt dag i skabelsen, og en filosofisk baseret læsning af den guddommelige proces, der er stærkt påvirket af hans kabbalistiske studier. På mange måder er Camillos teater, med dets kabbalistiske grundlag, en faktisk model af den skabelsesproces, som Pico beretter om. Syv

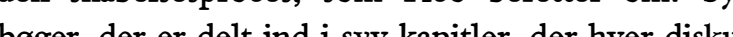
boger, der er delt ind isyv kapor, der huer diskuterer kos bolik i Heptuphs. disse bagers viden er det grundlæggende indhold i repræsentationen af de syv søjler Camilos teater. Bevaglsen mellem billederne udløser fantasien ved at genspille den genkendelige oprindelige skabelsesgerning.

Metafysisk udvikler sindet sig gennem det sefirotiske, mnemotekniske system og når op $i$ kabbalaen højere lag. Stedet, hvor disse to typer af bevægelse mødes, fysisk og metafysisk, er den symbolske markering af de syv søjler som de syv skabelsesdage: der er en tilbagevenden til den oprindelige gerning til den oprindelige erindring som implicerer en shas den oprindelige erinding, som mplicerer en slags tidsrejse, der gar fra den sor

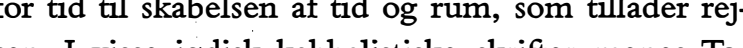
sen. I visse jodisk kabbalistiske sterter menes Toraen at eksistere uden for tid, for skabelsen, som fandt sted fordi Gud reciterede den hebraiske tekst. Så snart bevægelsen tilbage $i$ tid er opnået, går nutiden igennem stadier af kundskab i den første verden, som bebos af menneskene. Bevægelsen tilskrives sjælen, tre af hvilke Camillo betegner ved dere kabbalistiske navne: nephes, som han oversætter med "anima vivendi" eller den profetiske stemme, ruach eller den rationelle sjæl, og nessamah eller mens. Den første, nephes, er sjælen der er modtagelig for åbenbaring som skimter Gud gennem den tredje himmaris. mels slor. Kestem abstraker stimulerer, vil gennemtrange den som vertue sende ganske fa ind i den mystiske forening, som inder sted $i$ den tredje himmel.

Det vil sige, at det højere intellekt stimuleres af værdige billeder, som netop er dem Camillo genskaber med det formål at bringe udøveren af teatre tættere på Gud. Det mest virkningsfulde billede er billedet af Kristus, således at rejsen er en imitatio dei, en gengivelse af Kristi lidelseshistorie, der er en integreret del af den katolske liturgi. Den kontemplative rejse kan bedst bestrives som en rejse gennem forskellig planer, symboliseret ved henrykkelsen som mors osculi eller dødens kys fremprovokerer. Dette finder sted på teatrets femte trinrække, hvilket inplicer, at der er mere at erfare. Faltisk le ket illo at dristologisk betydning i kyset sset ved Ther for bringer sjælen tæattere $\mathrm{p}$ Kristus (Fil. 1.23). Camillo mente, at den endelig forening var hæmmet af legemligheden, selvom a snittet også antyder at legemlighedens hindring visse tilfælde kunne overvindes, som det måske var tilfældet med Paulus, hvis bimmelfart kunne have været en ud-af-lroppen oplevelse, men selvom legemligheden overvindes, er oplevelsen stadig en gentagelse af den arketypiske erindring om Kris liv, i en historisk cyklus, der ligger uden for tid. Hos Bruno er præsentationen af Paulus' mulige ud-af-kroppen oplevelse meget anderledes $i$ sin struktur, sit rum og i forhold til rejsens vej. Den første åben ste abering (a) hvilket in nerede døden som blot en losrivelse fra den legemlige tilstand. Denne mangel pà interesse for det legemlige forklarer muligvis også, hvorfor Bruno forblev inden for den todimensionale mnemotekniske billedtradition, som tilvejebragte et mentalt navigationsmiddel snarere end et fysisk, men hvi symbolske karakter var gennemtrængt af kraft. Pa samme måde som i sefirah Hokhmah, der så passende repræsenterer den ottende sfære, som fremdriver universets bevæegelse. Det vil sige, at fokus på Hokhmah nedbringer tilstrømningen ikke bare fra denne emanation men også fra den universelle bevegelseskrnft som på sin side giver kraft til den shes oplever, som Onorio bestriver. De epioderidialocen som bestever de hendeler, der sker for samtalepartent sis fungerer som en er tilerne som ens verd en menneskelig oplevelse. I fantasiCamillos systemer. Cabala illustrerer tydeligt Brunos tro på metempsykose, sjælens over- og underjor- 
diske rejse, såvel som på den uophørlige cyklus af livsrejser gennem hvilke viden akkumuleres gennem oplevelse, hvorefter det huskes og opsamles i disse livs erindring. Mange af de mytologiske billeder som Bruno bruger i sin tekst har at gøre med rejsen, f.eks. den bevingede hest Pegasus som ledsager Perseus $\mathrm{på}^{2}$ forkellige ferntligende eventyr, men cur (de mane in oprindelige gyldne asel), son ogsa faviede alle de store filosoffer siden Aristoteles. Tidsrejsen med Onorios inkarnationer har sine bistoriske grænser, trods det at doktrinen om metempsykose unddrage sig en ren menneskelig tid til fordel for evighedens cyklus, med en tilbagevenden til eksistensen uden for tid i den arketypiske verden. Bevægelse er ubegrænset i den menneskelige eksistens' to verdener og $i$ den arketypiske verden, hvis geografi er grundigt dokumenteret i Onorios beretning. Bevægelse inden for det uendelige univers indbefatter også bevægelse mellem uendelige verdener, hvilket er nødvandigt for selve elsistensen of kosmos og af encer de denmed af einding. Kort sagt, Bhy mente at 列

Et problem som Bruno fandt mere interessant var kroppen, de forvandlinger som den mystiske oplevelse i sig selv gennemgår, efterfulgt af et uendelig antal mulige variationer, hvis sjelen vandrer. Hvor Camillo søgte at forstærke intellektet med en fysisk, taktil oplevelse af at bevæge sig gennem et rekonstrueret Vitruvius-inspireret teater, da ryddede Bruno det fysiske redskab af vejen til fordel for en metafysisk oplevelse, som han ville argumentere for var mere virkelig, eftersom det nåede sit højdepunk i uendelige inkarnationer, det vil sige, uendelige kropsoplevelser. renctisk gennem metempsykose pa en made, der ville havde været bandlyst for Camillo, der mente at Ordet var legemliggort i Jesus, mens Bruno tilbød et væsen, der bar Messias 1 en menneskelig skikkelse. Men Camillo kun foreslog en ud-af-kroppen oplevelse, gav Bruno levende beskrivelser af adskillige. Den samme krop, som Camillo anså for at være en hindring for den mystiske forening, er på malende vis

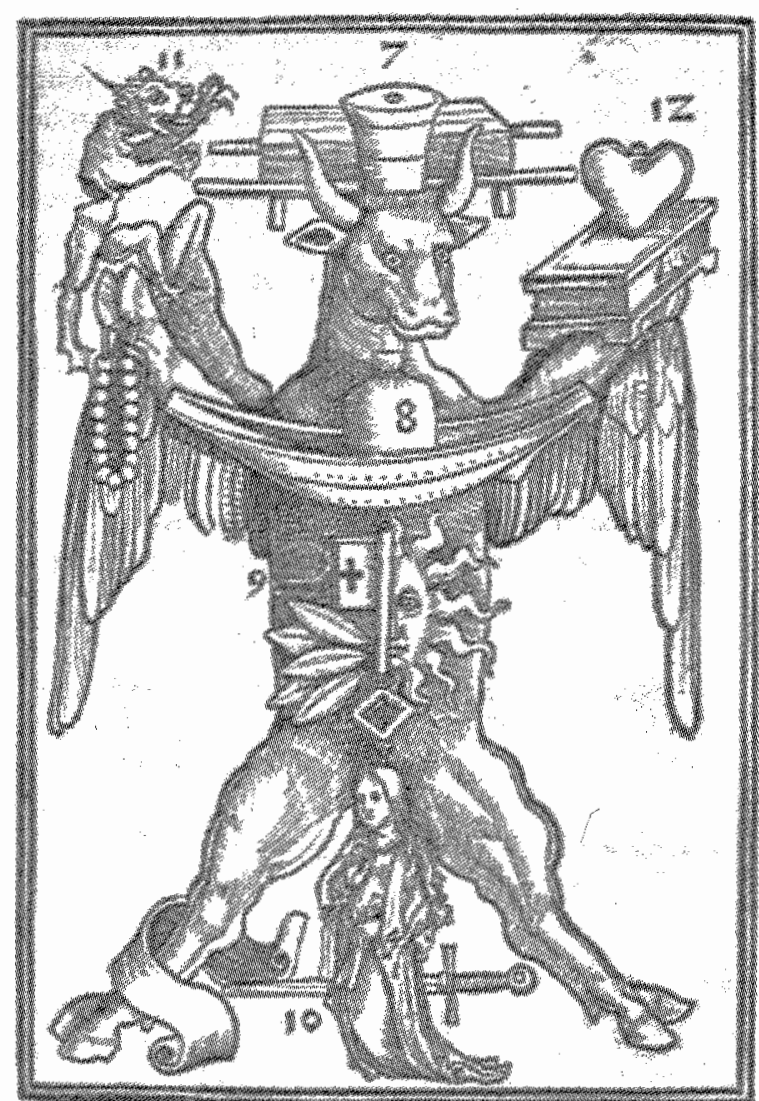

Mnemoteknisk figur til Lukasevangeliet, hvor hver enkelt ting

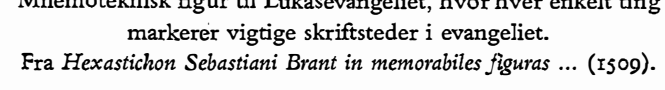

forvandlet til et grotesk æsel, som Bruno hævdede var symbolet pà den mystiske tilstand af asinita (en tilstand af negativ teologi), som han ydermere hævdede var en kabbalistisk tro (tydeligvis hans egen opfindelse), der finder udtryk i sefirot-træet. For Bruno lo rejen soles mere inden for en metar belighed - som ban kelighed - som han me eller mindre selv havde skabt der findes i judnismen og kistendommen. Bestrobelserne er ikke så meget samlet om at skabe et enkeltstaende værk, der indeholder al viden (hvilket ville være en meget kabbalistisk idé), men om at levendegøre bestemte episoder som bringer de grundlæggende principper i Brunos filosofi til sinds: et udgangspunkt snarere end en selvstændig model. Fra en filosofisk synsvinkel tilbyder Brunos skrifter et mønstergyldigt eksempel til inspiration for den kreative proces hos andre.

Ånden i Cabala er tættere på de klassiske traditioners poetiske modeller, som f.eks. hos Ovid of Verill og pa den poetiske raptus, der ligger nar fili, og pá den poetiske ( omend begge tænkere er optaget af problemet om den menneskelige indsigts kilder. I modsætning ti Camillo er Bruno mindre interesseret $i$ erindring som grundlaget for kreativitet eller skabelse, end han er $i$ erindringens evne til at tillade os at genskabe. Erindring fører til en forening med Gud, som forer til sjælevandring, som fører til evig erindring. En perfekt cyklus, der med dens direkte kommunion med Gud er meget tættere på det protestantiske begreb om umiddelbarhed, og paradoksalt nok også tættere på den jødiske kabbala med dens fokusering på sefirot som et middel til at nă Gud, det vil sige et pa sefle of ensidi tilstromning af paiviturge par tatio dei som spirituel vej.

Imago - forestilling

Det underliggende tema i begge værker er, at men ved at søge indsigt søger Gud. Erindring er grundlaget for indsigt, eftersom sindet, der ikke kan huske viden, heller ikke vil være i stand til at bearbejde viden. Begge forfattere præsenterer mnemoteknikker, der er udviklet $\mathrm{i}$ overensstemmelse med forskellige principper om indsigt, og inspireret af helt særskilte forestillinger.

Camillos teatermodel er sandsynligvis det første

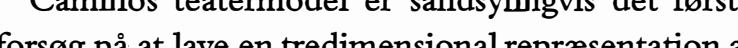
forsog a lavention af lige kosk) var popula menneske) var populære i det sekstende arhundrede, men mig bekendt var der ingen tredimensionale representationer af disse konfigurationer. En sådan udtalt billedliggørelse var et særligt. kristent fænomen, da forbudet mod repræsentationer af Gud og guddommelige skikkelser var for stærkt i judaisme til at kunne tillade, at selv sefirot således blev gjort til genstand for detaljeret ikonografi, for ikke at tale om tredimensionale modeller. Desværre er der ikke nok detaljer $\mathrm{i}$ beskrivelsen af teatermodellen til at kunne fastslå, hvordan Camillo portrætterede sefirot, om deres navne blot var stencileret med latinske (eller hebraiske) bogstaver på den forste trirelle billeder.

Erindring er for Camillo et arbejde, en kreativ handling af tilføjelse, association og analyse, som aldrig vil føre til den absolute indsigt eller til den fulde forening af mens med det arketypiske intellekt. Erindring definerer mennesket som mikrokosmos kosmos. I kabbalistiske termer mente han, at indsig opstår på det sefirotiske niveau umiddelbart før $\mathrm{Bi}$ nah, det vil sige det punkt Moses nåede ved sin åbenbaring på Sinai. At indsigt, erindring og skabelse er nær forbundne er tydeligt $i$ lange passager fra skabelsesmyterne, hvad enten det er Skabelsesberetningen, Poimandres eller Zohar. Den forste og den sidste er naturligvis nesten sammenfilende, eftersom ka Skater Slabelseshet kedse pa det idlep. Deser havde lært mysterierne af Kgypterne mens han var søn af Farao, og at han modtog direkte abenbaring ('kabbala' i den direkte oversættelse af det hebraiske). Dette giver også mening, hvis man tager et par ting $i$ betragtning. For det første, at den første manifestation af det arketypiske intellekt, Den første bevæge i neo-platonismen, netop er skabelsen af universet. Og for det andet, at når mennesket først er skabt i billedet af Gud, imiterer mennesket den kreative proces på sit eget niveau, hvilket er i nær overensstemmelse med Picos tidlige filosofiske skrifter. Grundlaget for kreativitet er erindring evmen til at huske og byge videre po tilegnet viden ud fa ferdigheder, oplevler elle direte ovefoing. Desto ther desto the ken

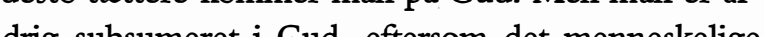
ind ikke $i$ and, efterson det menneskelige Sømmen tan

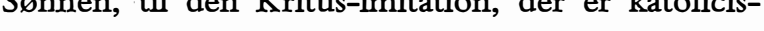
mens grundlag. Erindring er således i sidste ende svar pa Kristi lidelseshistorie. Camulos brug af kabbalaen svarer i al vasenligt til Picos, at der i disse 
sias; det vil sige, den er kristologisk. Camillo vedbliver altså i den sidste ende at være tro mod den katolske lære.

Ifølge Cesare Vasoli var Camillo stærkt influeret af tre af periodens store mystikere: Jacques Lefevvre d'É

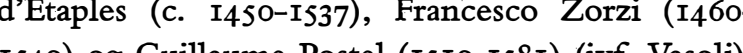
1540) og (c. rillso-re Post) (Is10-1581) (jvf. Vasoli). Og der er bestent paraller mellen den kabbalistiske åndelighed i L'idea del theatro og Zorzis De harmonia mundi (I525) og Postels Absconditorum clavis (I547?). Særligt interessant er Postel, som sandsynligvis er en af de få kristne, der faktisk var kabbalist, eftersom han betragtede kabbalaen som kilde til profetisk inspiration. I en eksegetisk tone og teknik analyserer Camillo Skabelsesberetningens hebraiske tekst i forhold til problemet om legemlighed, og han påpeger at termen 'billede' er givet som celem, mens 'lighed' er givet som demut (Camillo, p. I22). Han fortsætter med en fortolkning fra Zohar (I, 25\%. III 207c-208a), bor celem angiver englar (I, 25a; III, lem-208), men demut angiver den guddomnetige tistand. Herefte vender han tilage til Skabelsesberetningen, til skabelsen og til termen adema, som pa hebraisk betyder en bestemt slags rød jord, men det er ogsa æællesbetegnelsen for menneskeheden, og hvorfra navnet Adam stammer, forfaderen hvis billede (celem, demut) frelseren Kristus tager på sig for at udfri menneskeheden fra den oprindelige synd: et elegant etymologisk ordspil for at vise gyldigheden i det kristne budskab. Der findes også en himmelsk Adam: Adam Kadmon som er en af udlægningerne af sefirot. Det kan ikke have undveget en mand, der var berømmet for sin lærdom $i$ kabbaleaen; at konfigurationerne af sefirot $i$ billeder som Adam Kadmon eller treet vir sefrot i billeder som Adam Kadmon eller træet var et mafttulde nok til at rumme spørgsmålet om mikro-
makrokosmos, om fysikalitet over for det uhåndgribelige.

Paradoksalt nok bliver den kabbalistiske diskurs mere og mere kristologisk efterhånden som Camilos tekst bevæger sig op igennem de højere lag. Imitationen af Kristi lidelseshistorie er en vanskelig vej at følge, så Camillo giver en menneskelig model í Paulus. Fra kabbalaen udleder Camillo den idé, a Gud skabte mennesket for at mennesket kunne ar- bejde for Ham, hvilket Camillo understøtter ved at citere fra Esajas (Es. 26.12). Han konkluderer derefter, at ethver god gerning udført af menneskene ikke er deres eone, men Guds, eftersom mennesket ikke er andet end et redskabs, eftersom ment

Referencen til det Ny Testamente forer igen til Referencen tidet $\mathrm{Ny}$ Testamente forer igen til Palnes som en eksegetisk fortsættelse af det Gamle Testamente, og hvis liv tjener som forbillede. For Camillo demonstrerer Paulus fuldbyrdelsen af det Gamle Testamentes profet både $\mathrm{i}$ forhold til hans opfattelse af Kristus som Messias og i forhold til hans eget livs ekstatiske himmelfart. I. Korintherbrev begynder netop som et bevis på, at der ikke findes indsigt, hvis ikke Kristu anerkendes. Dette bekræftes i citatet fra I. Korintherbrev. 4.7, som Camillo fortolker som et bevis pà det indre menneske, der begræder legemlighedens vægt (Jobs Bog IO.II). Denne kan undgås gennem sixlens progression, idet den $i$ sin bevegelse sjalens progression, idet den i sin bevægelse fra Nephes til Ruach til Nessamah forvandler sig før ternest i det femte lag til en gudeskikkelse (demut), som f.eks. Johannes Døberen eller Paulus. I det syvende lag præsenterer Camillo sin afgørende forestilling ved at erklære, at Paulus som prædikeren af I. Korintherbre I.I7 med glæde ville have omskrevet Johannesevangeliet til: „I begyndelsen var Kristus og Kristu var med Gud, og Kristus var Gud“ (Camillo, p. I75. Jvf. Joh. I.I). Hvis Toraen eksisterede før Skabelsen, oplæst af Gud Skaberen, og hvis Kristus var Skaberen, må evangeliet have eksisteret sammen med Toraen fra begyndelsen, for at det kan være en fortsættelse af den anden. Det vil sige, at Camillo egen syvidele ekse er en bekreftelse af det mesfor meslise labbo sa jo diske kabbala, samidig med, at han klandrer joderne for ike at acceptere Kristus som Messias. Den kabbalistiske teologi 1 Theatro vedrører i sidste ende Zohar, såvel som evangeliet vedrører Toraen, et forsøg på at demonstrere kontinuiteten i opfyldelsen af den jødiske profeti, samtidig med at Theatro også markerer spittelsen mellem de to trosretninger på baggrund af den jødiske fornægtelse af den endelige åbenbaring.
Åbenbaring og profeti er lige så vigtigt for Bruno Cabala, selvom spørgsmålene er udtrykt på anderledes vis. Dette skyldes delvist, at Bruno ikke var sà direkte influeret af de visionære kristne kabbalistiske skrifter af $f$ eks. Pico, Postel eller Zorzi. Hans egme srifter profetiske a segesen og prot af kabbalistiske tilgange. Bibele og kabbalan er stort set det same for Bruno, der henter sine citater og modeller fra det Gamle Testamente, særligt fra Bileam, Moses og Salomon, som han tilskriver mange kabbalistiske ideer.

Bruno illustrerer på uærbødig vis sine teorier med billedet af æslet, som han associerer med profetiske bibelske figurer. Bruno vælger at repræsentere sin kabbalistiske doktrin om metempsykose, som han tilskriver Salomon og saddukæerne, ved at bruge de skæmtsomme billeder af Onorio (æslet som filosof), der rejser gennem underverdenen. Onorio er tydeligvis en satirisk figur, som ikke 'skal fremstå som et monstereksempel, men monsterckerter heller Pave i care tillo Paulus i Camillos Theto. Der gives passende eksempler fra Bibelen, som da Gud taler med æslets stemme $i$ en episode med troldmanden Bleam, der efterfølgende spår om storheden $i$ antal, kraft og vælde hos Israels folk, der nedstammer fra Jakob. $\mathrm{Og}$ for at give et eksempel fra det $\mathrm{Ny}$ Testamente påpeger Bruno, at Jesus' triumftog gennem Jerusalem foregik på ryggen af et æsel; det vil sige, at analogien går så langt som til at foreslå, at æslet er med frelseren, gennem doktrinen om asinità.

Asinità er den mystiske værenstilstand, som opnås fra den fjerde sefirah og indtil Hokhmah for den mulige menneskelige opnåelse, of som i sidste in stans farer til en mental sammensmeltning midste instans for til en ter eller Den arkeypise fort sets princip (Bno, p. 866). Hokhmah rydder vejen ved at tilvejebringe grundlaget for en guddommeligt inspireret indsigt. Der kan opnås mere i de højere lag, efterhånden som mens bliver et med det oprindelige intellekt, og først da bliver åbenbaringe fuldstændig, som det skete for Moses. Ifølge Bruno var alle de, der var berømmet for deres visdom, berørt af Hokhmah og subsumeret i asinità.
Et minus ved den komplekse billedverden, der associeres med æslet og asinità, er, at Bruno i sidste ende ikke er i stand til at bevare fokuset $i$ sit profetiske budskab på én figur, hvilket Camillo så vellykket formår med Paulus-Kristus figuren. Dette lycket for for skyldes for en stor del ogsa B logiske ideer: hvordan den etablerede religion, fremstille et enkelt mønstereksempel, uden at det fremstår som en erstatning for Kristus? Selv de mest radikale protestantiske reformatorer afskaffede forbønnen, men ikke Kristus som frelseren. I bedste fald fremstiller Bruno i malende detaljer hellige rabbineres og kabbalisters metamorfose til æsler, som en metafor for forsagelsen af menneskelig indsigt til fordel for guddommelig åbenbaring. Når de tre sindsevner koncentreres $i$ en ny form (nu en, ikke tre sjæle), forhindrer den nye hov det forvandlede menneske $i$ at gentage Adams gerning; han er i stedet tvunget til at adlyde Guds semp; derer, og at handle deref (Blart en ny fortolkning af passagerne fra Esajas og Korin brevet som Camillo også brugte som modeller.

Dette er Brunos (umulige) model, der skal frisætte hvad Camillo havde kaldt det indre menneske fra legemlighedens fængsel, og Brunos svar på spørgsmålet er metempsykose. Onorio forstod, da han afviste at drikke vandet fra Lethe, at alle væsener, alle sjæle er del af det ene (Ein sof): åbenbaringen afslører ikke blot, at alle sjæle er del af anima mundi; den er også sjælevandringens cyklus, der afviser evig død. Det vil sige, at Bruno omskriver det kristne budskab om evigt liv til en negation af den sande død. Det drejer sig ikke langere om gode gernincer eller forthestemmelse, men om for den enkelte at anvende indigt for at hine fores med den universelle guddom $i$ et uendeligt renoutio. Fordi Buno valger at tils

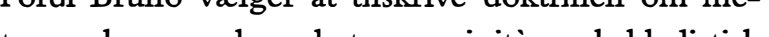
eller hebraisk oprindelse, af aintà en kabbistisk

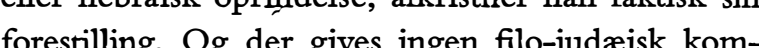
fores institutionaliseret religion. 


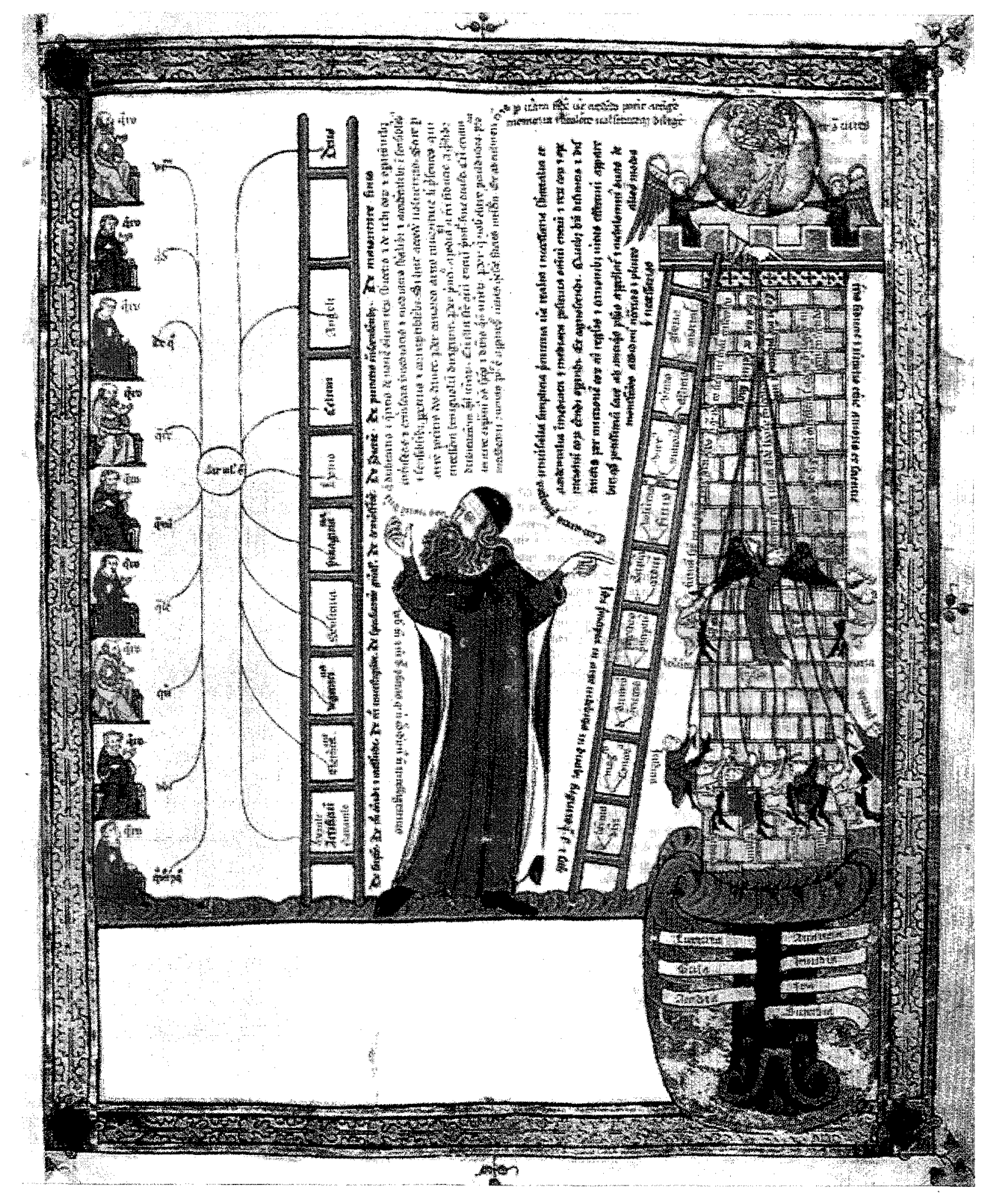

Konklusion

For bedre at kunne sammenstille diskussionen af de to værker $i$ en konklusion er det oplagt at vende blikket mod deres omfattende brug af kabbalaen, og stille spørgsmålet om Bruno og Camillo skal betragtes som kabbalister? Spørgsmålet rejser nemlig mange andre spørgsmål, som tvinger os til at revaluere vores opfattelse af det kristne samfund i det sekstende århundrede. Betragtede de sig selv som kabbalister? Og hvis ikke, er deres brug af kabbalaen så blot en fashionabel hermeneutisk stillingtagen? Med andre ord, ved at fokusere på to forskellige generationer af forende tænkere fra det sekstende århundrede, Bruno og Camillo, bliver det ikke blot nemmere at forsto den kabbalisiske anv fa Pico dell a Mirandola men ogso den direkte folge af han banebrydende samordning af jødisk tænkning og kristen tro.

Nogle fă fællespunkter viser den måde som den kristne kabbala fors 6 te at intere det messianske og profetiske, som var iboende deres tro, i traditionens jødiske rodder Det skal dere und profeti som et primært anliggende, inden udbredelsen af kabbalistisk tænkning $i$ jødiske lredse, var en

kristen interesse og ikke en jødisk. Messianismen var traditionelt set mindre overbevisende og mindre velformuleret i den gængse judaisme end de kristne ville vide af: Picos oprigtige overbevisning om, at kabbalaen som et middel til at omvende joder ved abenbare de bistologiske strukturer, som opfyder (like virkningstuldtet piddel som truslen om fysisk vold. Messianismen var et af de emner som adskilte den kristre kabbala fa dens jodiske rodder. Et noglebegreb'i den jødiske tro har altid været, at Messias ville være en mand som fysisk frelste jøderne, og bvis åndelige budskab ville være at tillade udbredelsen af judaismen. Den kristne messianisme, som findes hos Postel eller Camillo, er fjern fra den jødiske forståelse af begrebet. Den kristne profeti drejede sig om den universelle gyldighed i det kristne budskab om frelse gennem Jesus, og den blev sekterisk efterhånden som kristendommen blev oplost $i$ forskellige kirker op igennem reformationen.

I sidste ende måtte kristendommen omdanne kabbalaen, hvis den skulle være sand $i$ forhold til kristendommens eget messianske og profetiske budskab om imitation dei. Kristendommen måtte genskabe åbenbaringen for at kunne skabe en ny kabbala, ligesom det $\mathrm{Ny}$ Testamente indlemmer det Gamle Testamente for at skabe den kristne Bibel, der er så fjern fra Det der i særlig grad i de to varker, at den kabbalistiske diskurs er forbundet med erindring. Eksegese er nøglen i begge værker, hvor genlæsninger og genfortolkninger af bibelske tekster til tider ender med overraskende og meget personlige konklusioner. Camillos forestilling var $i$ bund og grund kabbalisCark isk pave for jodiske bider som fels. Zohar. 1 den sidste foresilyg, huor Toraen end $Z$ enangeliet af Skaberen Kristus, lader Camillo ane at erindringen er den skabende kraft, der er $i$ stand til at drive mennesket frem mod Gud. Den blotte erstatning med navnet Kristus i stedet for Gud demonstrerer underforståelsen af fantasiens kraft, der lader kristendommen afløse judaismen. 
For så vidt at Camillo demonstrerer en tæt forbindelse med den jødiske tradition i sin anvendelse af den jødiske kabbal $i$ sine skrifter $\mathrm{g} i \mathrm{indlyd}$. fra andre kistme kabbalisike tenkere, viser deten mand som i bvert tilfolde tog altiv del i den kristne kabblisike tadilon. On han betagede sis selv som svare, men jeg udelukker ikke muligheden.

Den absolutte erindring er indeholdt $i$ det forst intellekt, så tæa på Gud som Bruno vil tillade i sin filosofi. Han genvinder fra erindringen kun de kabbalistiske ideer som er forligelige med hans egne. Omdannelsen af troen er mere radikal hos Bruno, som går så vidt som til at foreslå en ny version af myten om den gyldne kalv som en forklaring på associationen mellem jøderne og xslet (Bruno, 867). Disse friheder kan tillades of en mand, hvis fantasi er sing dring er en siig tilstan dring er en evig tilsted som den individuen mens la tage med ig frac in ink lfølge Brano er gengivelsen af skabelsen ilke en imtatio dei, men en aktiv deltagelse i skabelsen som en forlængelse af Den første bevægers tilstedeværelse alle ting. Bruno er ikke en tænker, der i særlig grad er tiltrukket af kabbalaen som mystisk retning; han er nok snarere en tænker, som integrerer de kabbalistiske aspekter $i$ et personligt udviklet system for a vise evnen til at inkludere alle manifestationer i sin egen filosofi. Han er med andre ord ikke særlig optaget af kabbalisternes fordring om direkte åbenbo ring, bvilket de kristme trakere, der soger inspiration i kabbalaen, er.

Den eneste overordnede konklusion, der kan giDesi eneste overor vesi denne korte sammen plekse tankere, ex, at kabbalaen i det sekstende ârhundredes kristendom er tæt forbunden med tiden religiøse spørgsmal. En katolik som Camillo integrerede kabbalistiske forskrifter i sin spiritualitet i e sådan grad, at kabbalaen blev hans kreative kilde. En ikke-troende (for at låne Lucien Febvres term) som Bruno, der afviste religiøse traditioner, havde langt mere ambitiost forhold til enhver åndelig ret-

Pà forrige side ning. Bruno foretrak at fokusere på individet $i$ en hyldest til den menneskelige kreativitet, hvilket varslede en før-moderne læsning af Picos berømte Oration.

På dansk ved Mette Jorgensen

Litteratur

Bruno: La cabala del cavallo pegaseo.(I585). Firenze: Sansoni, 1985 (1958).

duzione e note a cura di Lina Bol del Theatro ( 1550 ). Intro(L'Italia. 2), I99I.

Karen de Leon-Jones: Giordano Bruno and the Kabbalah Prophets, Magicians and Rabbis. New Haven: Yale UP (Yale Studies in Hermeneutics), 1997 .

Giovanni Pico della Mirandola: Antologia di Giovanni Pico della Mirandola: passi scelta da Heptaplus, Oratio de hominis Guse, De ente a no. Throduzione, traduzione e noti [Basel?] [r547?].

Johannes Romberch, Congestorium Artificiose Memorie. Venedig: Giorgio de'Rusconi, $\mathrm{I}_{533}$ Paris: Dunod (Collection Sigma. 5), 1964 .

François Secret: Le Zohar chez les Kabbalistes chrétiens de la Renaissance. Paris-La Haye: Mouton, r964.

François Secret: "Les cheminements de la Kabbale à la Delminio et son influence" in Rivista criticalio Camilo

Sefer Yetzirah = The Book of Creation. English and Hebrew;
commentary in English Aryeh Kaplan. York Beach, Me.: Samuel Weiser, 1990

Cesare Vasoli: I miti e gli astri. Napoli: Guida (Esperienze.

Frances A. Yates: Giordano Bruno and the Hermetic Tradition. Chicago: University of Chicago Press, 1964

Anory. Chicago: University Chicago Press, 1966.

with an introduction Herry Sperling and Maurice Simon oncino press, [1956]. 5 bd.

Francesco Zorzi: Francisci Georgii Veneti minoritanae familiae De harmonia mvndi totivs cantica tria. Venetiis: In dibus Bernardini de Vitalibvs Calchographi, I525. 